\title{
Reduction of Salmonella Enteritidis in Fish by Microwave Cooking
}

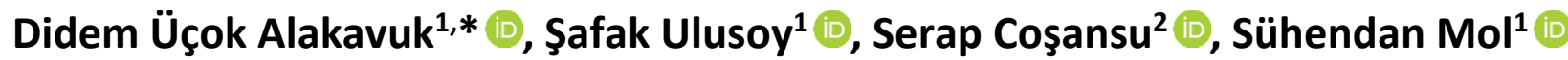

${ }^{1}$ Istanbul University, Faculty of Aquatic Sciences, Department of Fisheries and Seafood Processing Technology, Ordu Cd. No: 8, 34134 Laleli-Fatih, Istanbul, Turkey.

${ }^{2}$ Department of Food Engineering, Engineering Faculty, Sakarya University, 54187 Sakarya, Turkey

\section{How to cite}

Alakavuk Üçok, D., Ulusoy, Ş., Coşansu, S., Mol, S., (2021). Reduction of Salmonella Enteritidis in Fish by Microwave Cooking. Turkish Journal of Fisheries and Aquatic Sciences, 21, 535-540. http://doi.org/10.4194/1303-2712-v21_11_01

\section{Article History}

Received 05 February 2021

Accepted 01 July 2021

First Online 12 July 2021

\section{Corresponding Author}

Tel.: +902124555700

E-mail: ducok@istanbul.edu.tr

\section{Keywords}

Microwave

Salmonella

Fish

Salmon

Whiting

\begin{abstract}
The effect of microwave cooking on the survival of Salmonella Enteritidis was investigated. Inoculated whiting and salmon fillets $\left(6-7 \mathrm{log} \mathrm{cfu} / \mathrm{cm}^{2}\right)$ were cooked in microwave either packed or unpacked at two internal temperatures $\left(50\right.$ and $\left.70^{\circ} \mathrm{C}\right)$. When the samples were cooked up to the internal temperature of $50^{\circ} \mathrm{C}$, the reductions were $1.82 \mathrm{log} \mathrm{cfu} / \mathrm{cm}^{2}(29 \%)$ for packed and $0.69 \mathrm{log} \mathrm{cfu} / \mathrm{cm}^{2}(11 \%)$ for unpacked whiting. For the same cooking temperature, the reductions were $2.39(33 \%)$ and 0.73 $\log \mathrm{cfu} / \mathrm{cm}^{2}(10 \%)$ for packed and unpacked salmon, respectively. When the internal temperature was $70^{\circ} \mathrm{C}$, the reductions in $S$. Enteritidis counts were $2.89(45 \%)$ and 3.90 $\mathrm{cfu} / \mathrm{cm}^{2}(54 \%)$ unpacked whiting and salmon, respectively. However, the reductions were higher in packed samples of both fish cooked to $70^{\circ} \mathrm{C}$ internal temperature than that of unpacked samples and counts of the pathogen were below the detectable level $\left(<1.00 \mathrm{log} \mathrm{cfu} / \mathrm{cm}^{2}\right)$. These results suggested that packaging increased the $S$. Enteritidis reduction during microwave cooking and the reductions were higher in salmon than that of whiting. Microwave-cooking instructions must be included in the MW operating manuals. The foods must be cooked in microwave not lower than $360 \mathrm{~W}$ and $70^{\circ} \mathrm{C}$.
\end{abstract}

\section{Introduction}

In recent years, the microwave oven has become an essential appliance in most kitchens. The percentage of homes possessing microwave ovens is approximately 93-95\% in the United States, $97 \%$ in Japan and $90-95 \%$ in the United Kingdom (Horikoshi et al., 2018). The use of oven is remarkably popular in commercial and home cooking, since it is faster and more practical than conventional methods (Giese, 1992; Tassinari \& Landgraf, 1997; Thostenson \& Chou, 1999). In addition to the increasing use of microwave oven at home, it has also been used in industrial food processing systems. Efficient operating conditions, compatibility with other equipment, and increased product quality are the advantages of microwave to traditional heating methods. Microwave heating is a sustainable and ecofriendly technology that reduces adverse environmental impact and power consumption (Komarov, 2021). Delivering high temperature in a very short time results in nutritional and sensorial advantages over the traditional cooking techniques (Aymerich et al., 2008; Orsat et al., 2017).

In conventional thermal processing, energy is transferred from surface to the inner parts of the food via convection, conduction, and radiation. In contrast, microwave energy is delivered directly to the food through molecular interaction with the electromagnetic field (Thostenson \& Chou, 1999). In a microwave oven molecular friction between water molecules, under an oscillating electric field of specific frequency, increases the temperature of food (Pucciarelli \& Benassi, 2005). 
Microwave energy is used for heating, cooking, pasteurization, and sterilization of foods (Datta \& Davidson, 2001; Giese 1992). It is known that microorganisms in food are inactivated by the thermal effect of microwave (Vela \& Wu, 1979). However, incomplete inactivation of pathogens in foods, cooked or reheated in microwave ovens, has been reported (Burdick et al., 1983; Coote et al., 1991; Farber et al., 1998; Harrison \& Carpenter, 1989; Hollywood et al., 1991; Huang et al., 1993). Microwave cooking promises to reduce the time spent on cooking. However, cold spots in microwave-cooked foods pose a food safety risk for the consumer. It is challenging to detect hot and cold spots that occur in packaged foods during microwave cooking and to evaluate the temperature distribution within the food (Das \& Banik, 2021). Foods have complex natures, and electromagnetic distribution is not homogenous in the cavity. These properties have important effects on power absorption during $\mathrm{MW}$ cooking and the temperature distribution (Bedane et al., 2021). It is estimated that $9 \%$ diarrheal illnesses that occur worldwide annually are associated with Salmonella. Although Salmonella is the fifth most common pathogen, the mortality is high and $41 \%$ of all diarrheal disease-associated deaths can be attributed to Salmonella (Besser, 2018). Outbreaks associated with Salmonella resulting from the consumption of undercooked food are of much concern throughout the world (Evans et al., 2000). Although there are some studies on microwave-induced destruction of Salmonella in meat, poultry, and milk (Aleixo et al., 1985; Bookwalter et al., 1982; Evans et al., 1995; Levre \& Valentini, 1998), data for seafood is limited. Since it is an internationally important human pathogen and Salmonella Enteritidis outbreaks are generally related to undercooked foods (Humphrey et al., 1995), it is necessary to determine whether microwave cooking is sufficient to eliminate this pathogen in fish (Heddleson \& Doores, 1994; Datta \& Davidson, 2001). Whenever validating the cooking directions of a microwave oven, it is necessary to standardize the equipment and its set up to provide objective, repeatable use for the consumer. Validation is mandatory to ensure food safety and desired food quality (Vlock, 2020).

In this study, determining the efficiency of microwave cooking on Salmonella Enteritidis in salmon and whiting was aimed, as well as to determine the effect of packaging on destruction of this pathogen during microwave cooking.

\section{Material and Methods}

\section{Materials}

Frozen salmon (Salmo salar) and whiting (Merlangius merlangus) blocks were obtained from a local market in Istanbul, Turkey, and transferred to the laboratory in a chilled box within 30 minutes. Totally 120 fish pieces were used for each fish species. The shape of the fish blocks was a rectangular prism $(6 \times 7 \mathrm{~cm})$ with 2 $\mathrm{cm}$ in thickness. The upper and undersides of fish blocks were used as inoculation area and the total inoculation area was $84 \mathrm{~cm}^{2}$ for each of them. Fish blocks were thawed in the refrigerator ( 10 hours at $4 \pm 1^{\circ} \mathrm{C}$ ), before analysis.

\section{Preparation of Salmonella Inoculum}

Salmonella Enteritidis (Salmonella enterica serovar. Enteritidis ATCC 13076) pure culture was obtained from the culture collection of the Food Engineering Department of Sakarya University. Salmonella Enteritidis was activated twice in Tryptic Soy Broth (TSB; Merck, Darmstadt, Germany) at $37^{\circ} \mathrm{C}$ for 18 $24 \mathrm{~h}$. A tube containing $10 \mathrm{~mL}$ TSB was inoculated with active culture and incubated at $37^{\circ} \mathrm{C}$ for $24 \mathrm{~h}$. Following incubation, cells were harvested by centrifuging (Centromix, Selecta, Barcelona, Spain) at $3354 \times g$ for 10 minutes. The pellet was washed three times with sterile peptone water (0.1\%). Following washing, the supernatant was discarded and the pellet was resuspended in $10 \mathrm{~mL}$ of sterile peptone water $(0.1 \%)$.

\section{Inoculation of Fish Blocks}

Samples were inoculated with $S$. Enteritidis at a level of 6-7 log $\mathrm{cfu} / \mathrm{cm}^{2}$. A volume of $0.25 \mathrm{~mL}$ inoculum was deposited on one side of each block and was spread by a sterile bent glass rod to obtain an even distribution of the cells. The inoculated fillets were left for 15 minutes for inoculum attachment. The same procedure was repeated for the other side of each fillet. Environmental temperature was $10^{\circ} \mathrm{C}$ during the processes.

\section{Microwave Cooking}

Inoculated whiting blocks were separated into two groups (60 pieces). The first group was packed with a film (Polinas Polibarr Y10C1B, 90 $\mu$, the oxygen transmission rate of $160 \mathrm{cc} / \mathrm{m}^{2} /$ day, Manisa, Turkey), while the other group left unpacked. The same procedure was carried out for the salmon samples. All samples, whether packed or unpacked, were cooked in $2450 \mathrm{MHz}$ microwave oven at medium power (360 W, $30 \mathrm{~L}$ capacity, with a $34 \mathrm{~cm}$ diameter rotary plate, Bosch, Germany) to internal temperatures of 50 and $70^{\circ} \mathrm{C}$. To determine the risk that may occur in the case of inadequate cooking or preferring very rare fish, cooking at low temperature such as $50^{\circ} \mathrm{C}$ was studied as well as $70^{\circ} \mathrm{C}$. The internal temperatures were measured using a digital thermocouple (Multi, China, range $-50 /+150^{\circ} \mathrm{C}$ ) placed into the geometric center of fish blocks, immediately after cooking, as suggested by Vela and Wu (1979). The cooking times needed to reach to the target temperatures $\left(50\right.$ and $70^{\circ} \mathrm{C}$ ) for packed/unpacked fish were presented in Table 1. 


\section{Microbiological Analyses}

Each fish block was transferred to a stomacher bag with $90 \mathrm{~mL}$ of sterile peptone water (0.1\%) and homogenized using a stomacher (IUL Masticator, Barcelona, Spain) for $1 \mathrm{~min}$. Serial dilutions were prepared with peptone water $(0.1 \%)$ and $0.1 \mathrm{~mL}$ of appropriate dilutions were spread onto Xylose Lysine Tergitol4 Agar (XLT4; Merck, Darmstadt, Germany) for Salmonella enumeration. Additionally, $1 \mathrm{~mL}$ from the first dilution $\left(10^{-1}\right)$ was spread onto three XLT4 Agar plates. Thus, the lowest detection limit was 1 log cfu/ $\mathrm{cm}^{2}$. After incubation at $37^{\circ} \mathrm{C}$ for $24 \mathrm{~h}$, black or red colonies with black center were counted manually as $S$. Enteritidis. When the black colonies were not determined the samples were tested for the presence or absence of Salmonella (Andrews et al., 2020).

\section{Statistical Analyses}

Two replicated experiments were conducted and two samples per treatment group were analyzed before and after microwave cooking $(n=4)$. Data relating to microbial counts were subjected to ANOVA, using SPSS version 16.0 for Windows (SPSS, Chicago, Illinois, USA) and the Duncan test was performed for multiple comparison $(\mathrm{P}<0.05)$.

\section{Results and Discussion}

\section{Salmonella Enteritidis Reduction After Microwave Cooking}

S. Enteritidis counts of fish samples before and after microwave cooking are shown in Table 2. The initial counts of the pathogen on whiting and salmon samples were 6.37 and $7.23 \mathrm{log} \mathrm{cfu} / \mathrm{cm}^{2}$. S. Enteritidis counts reduced by microwave cooking depending on target internal temperature and cooking conditions. When cooked to the internal temperature of $50^{\circ} \mathrm{C}$, the reduction rates of $S$. Enteritidis in unpacked and packed whiting, were $0.69 \mathrm{log} \mathrm{cfu} / \mathrm{cm}^{2}(11 \%)$ and $1.82 \mathrm{log}$ $\mathrm{cfu} / \mathrm{cm}^{2}$ (29\%) (Figure 1$)$, respectively $(P<0.05)$. The reduction rate was $2.89 \log \mathrm{cfu} / \mathrm{cm}^{2}(45 \%)$ for unpacked, while higher than $5.37 \mathrm{log} \mathrm{cfu} / \mathrm{cm}^{2}$ (84\%) in packed whiting cooked at $70^{\circ} \mathrm{C}$. A similar result was observed for salmon samples. When cooked to an internal temperature of $50^{\circ} \mathrm{C}$, the reduction rates of $S$. Enteritidis in unpacked and packed salmon, were $0.73 \log \mathrm{cfu} / \mathrm{cm}^{2}$ (10\%) and $2.39 \log \mathrm{cfu} / \mathrm{cm}^{2}(33 \%)$, respectively $(P<0.05)$.
The reduction rates were $3.90 \log \mathrm{cfu} / \mathrm{cm}^{2}(54 \%)$ for unpacked, and higher than $6.23 \mathrm{log} \mathrm{cfu} / \mathrm{cm}^{2}(86 \%)$ in packed salmon, cooked at $70^{\circ} \mathrm{C}(\mathrm{P}<0.05)$. As seen in Table 2, Salmonella was not completely inhibited in whiting and salmon samples as a result of the presence/absence test. These were reflected in the results as ' $<1.00$ ' in the table. Microwave cooking resulted in the reduction of Salmonella Enteritidis, especially in packed samples at higher degrees, but did not eliminate this pathogen.

Huang et al. (1993) cooked catfish fillets in a microwave oven to internal temperatures varied from 55 to $70^{\circ} \mathrm{C}$, and reported incomplete reduction of Listeria monocytogenes and Aeromonas hydrophila. Incomplete inactivation of Salmonella spp. in microwave-cooked poultry feed (Burdick et al,. 1983) and chicken (Lindsay et al., 1986) has also been reported. Likewise, cooking in microwave oven to $76.6^{\circ} \mathrm{C}$ did not destroy Salmonella Typhimurium, Staphylococcus aureus and Clostridium perfringens in turkey meat (Aleixo et al., 1985). Tassinari and Landgraf (1997) evaluated the destruction of Salmonella Typhimurium during reheating of foods in microwave oven and reported the percentage of food samples positive for this pathogen as $47.8 \%$. Since a single Salmonella cell may constitute a human infectious dose (D'Aoust, 2000), we suggest that heating contaminated fish in microwave may not ensure safety.

As it was shown in Table 2, cooking to an internal temperature of $70^{\circ} \mathrm{C}$ resulted in lower $(\mathrm{P}<0.05) \mathrm{S}$. Enteritidis counts than that of $50^{\circ} \mathrm{C}$ for both fish species. Higher inactivation rates have also been reported for microwave-cooked red meat when temperature increased (Paterson et al., 1995; Yilmaz et al., 2005). Mendes-Oliveira (2020) studied the inactivation of Escherichia coli 0157:H7 and Salmonella Typhimurium by microwave and reported increased reduction up to 7 $\log \mathrm{cfu} / \mathrm{g}$, with the higher temperature, time and power. In another study, enriched corn-soy-milk blends were inoculated with Salmonella Senftenberg, and submitted to microwave heating. The higher reduction rates were observed at higher cooking temperatures and $S$. Senftenberg was reduced 2-log to 5-log after processing at $56.7^{\circ} \mathrm{C}$ through $82.2^{\circ} \mathrm{C}$, respectively (Bookwalter et al., 1982). Likewise, 5-6 log reduction has been reported for Salmonella in popcorns, cooked at higher temperatures (Anaya et al., 2008). Woo et al. (2000) have studied the inactivation patterns of the microwave-radiated cells using cell suspensions of $E$. coli and $B$. subtilis and reported 5-log reduction when

Table 1. Cooking times $(\mathrm{min})$ required to reach to the target internal temperatures $\left(50^{\circ} \mathrm{C}\right.$ and $\left.70^{\circ} \mathrm{C}\right)$ for unpacked/packed fish.

\begin{tabular}{lccccc} 
& \multicolumn{5}{c}{ Cooking Conditions } \\
\cline { 2 - 6 } Fish species & & $50^{\circ} \mathrm{C}$ & Unpacked & $70^{\circ} \mathrm{C}$ & Packed \\
\hline Whiting & Unpacked & & Packed & 5.0 & 3.4 \\
Salmon & 2.4 & 1.3 & 3.3 & 2.3 \\
\hline
\end{tabular}


cooked at $80^{\circ} \mathrm{C}$. In another study on the survival of Salmonella on half carcasses of chicken broilers during microwave cooking showed that long cooking times and higher temperatures were needed for the entire destruction of the pathogen (Gomółka-Pawlicka et al., 2014). Microwave cooking of fish reported to be effective to reduce E. coli 0157:H7, Staphylococcus aureus and Listeria monocytogenes, when their internal temperature is $50^{\circ} \mathrm{C}$ or $70^{\circ} \mathrm{C}$ (Ulusoy et al., 2019). It is clear that higher cooking temperatures increase the reduction rates.

\section{Effect of Packaging on Reduction Rates}

The reduction rates were higher $(P<0.05)$ for both fish species when cooked in a package (Table 2, Figure 1). In a study by Aleixo et al. (1985), microwave cooking in bags increased the destruction of Salmonella Typhimurium in whole turkeys. Likewise, Huang et al. (1993) cooked L. monocytogenes and A. hydrophila inoculated channel catfish fillets either uncovered or covered with polyvinylidene chloride films in a microwave oven and reported that covering fillets increased lethality at each temperature $(55,60$, and $\left.70^{\circ} \mathrm{C}\right)$.

\section{Effect of Fish Species on Reduction Rates}

Muscle foods are complex systems, mainly due to the presence of fat and proteins (Aymerich et al. 2008).
Fat accelerates the microwave heating rate and increases the effect of temperature (Jeong et al., 2006; Picouet et al., 2007). Juneja and Eblen (2000) have reported that increased fat levels in beef resulted in lower D-values, i.e. reduced heat resistance. Likewise, the time, needed to achieve the desired temperature is shorter in salmons, than that of whiting blocks in our study (Table 1). As it may be seen in Figure 1, reduction of $S$. Enteritidis was higher in salmon than whiting, especially when the samples were cooked to $70^{\circ} \mathrm{C}$. Garcia-Linares et al. (2004) reported fewer microbial counts in fatty species than that of lean fish after cooking. Salmon has been known as a fatty fish, while whiting has been known as a lean species (Tulsner, 1994). Our results are well correlated with these literatures, since the reduction rates of salmon were higher $(P<0.05)$ than whiting.

\section{Conclusions}

It was concluded that packaging increased the reduction of $S$. Enteritidis on fish during microwave cooking. Higher reduction was achieved in salmon samples than that of whiting. Therefore, these results suggested that the fish species were also important in terms of the risk of $S$. Enteritidis survival during microwave cooking. Cooking in microwave to higher internal temperatures increased reduction rates significantly $(P<0.05)$, but $S$. Enteritidis could not be eliminated completely in both fish species. Therefore,

Table 2. Salmonella Enteritidis counts on fish samples before and after cooking (log cfu/cm²)

\begin{tabular}{|c|c|c|c|c|c|}
\hline \multirow[b]{3}{*}{ Fish species } & \multirow[b]{3}{*}{ Before Cooking } & \multicolumn{4}{|c|}{ Cooking Conditions } \\
\hline & & \multicolumn{2}{|c|}{$50^{\circ} \mathrm{C}$} & \multicolumn{2}{|c|}{$70^{\circ} \mathrm{C}$} \\
\hline & & Unpacked & Packed & Unpacked & Packed \\
\hline Whiting & $6.37 \pm 0.06^{a}$ & $5.68 \pm 0.07^{c}$ & $4.55 \pm 0.68^{b}$ & $3.48 \pm 0.26^{d}$ & $<1.00 *$ \\
\hline Salmon & $7.23 \pm 0.73^{a}$ & $6.50 \pm 0.13^{c}$ & $4.84 \pm 0.30^{b}$ & $3.33 \pm 0.24^{d}$ & $<1.00 *$ \\
\hline
\end{tabular}

${ }^{a-d}=$ Different letters in the same row show the significant differences $(P<0.05)$ between the groups

* Salmonella-positive after enrichment

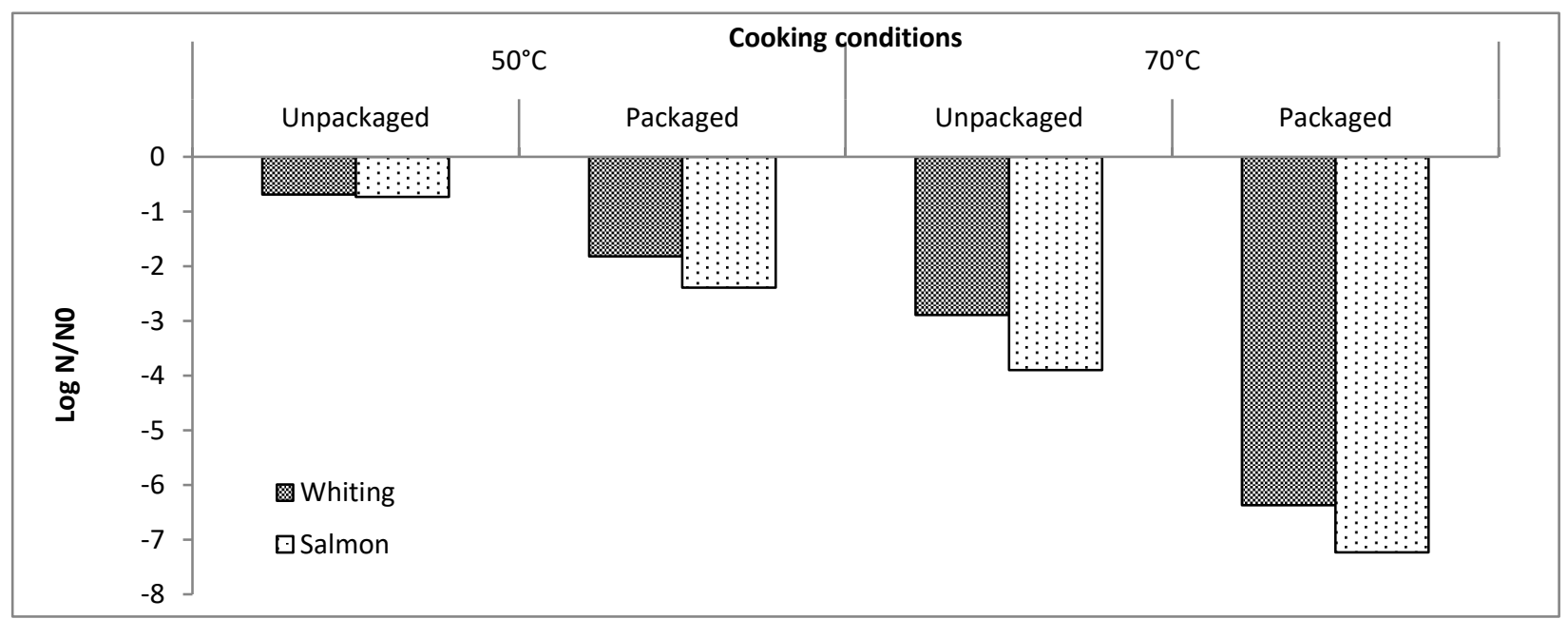

Figure. 1. The log reductions of Salmonella Enteritidis $\left(\log \mathrm{cfu} / \mathrm{cm}^{2}\right)$ counts on fish samples after microwave cooking. 
even packed or unpacked cooking the fillets to an internal temperatures of $50^{\circ} \mathrm{C}$ and $70^{\circ} \mathrm{C}$ was considered inadequate to destroy $S$. Enteritidis.

Considering the popularity of microwave cooking, results of this study will be important regarding food safety. Microwave cooking instructions for fish should be prepared considering the risk of uneven heating and bacterial survival. The data presented in this paper may be interesting either for the standardization of microwave ovens for domestic use, or for ready to eat food producers, when preparing HACCP plans.

Microwave-cooking guidelines for the domestic purposes and /or food service facilities must be included into the $\mathrm{MW}$ operating manuals. The MW-cooking guidelines and HACCP plan for food service facilities must be determined accordingly. The foods must be cooked in microwave not lower than $360 \mathrm{~W}$ and $70^{\circ} \mathrm{C}$. Microwave cooking foods in package is recommended.

\section{Ethical Statement}

This article does not require IRB/IACUC approval because there are no human and animal participants.

\section{Funding Information}

This study was supported by the Research Fund of Istanbul University. Project Number: BYP-3237.

\section{Author Contribution}

First Author and second Author: Data curation, Writing - review \& editing; Third Author: Methodology, Writing - review and editing; and Fourth Author: Conceptualization, Methodology, Writing - review \& editing.

\section{Conflict of Interest}

No potential conflict of interest relevant to this article was reported.

\section{Acknowledgements}

This study was supported by the Research Fund of Istanbul University. Project Number: BYP-3237.

\section{References}

Aleixo, J.A., Swaminathan, G.B., Jamesen, K.S. \& Pratt, D.E. (1985). Destruction of pathogenic bacteria in turkeys roasted in microwave ovens. Journal Food Science, 50, 873-880. https://doi.org/10.1111/j.1365-2621.1985.tb12969.x

Anaya, I., Aguirrezabal, A., Ventura, M., Comellas, L. \& Agut M. (2008). Survivability of Salmonella cells in popcorn after microwave oven and conventional cooking. Microbiological Research, 163, 73-79.

https://doi.org/10.1016/j.micres.2006.03.010
Andrews, W.H., Wang, H., Jacobson, A., Ge, B., Zhang, G. \& Hammack, T.S. (2020). Salmonella, Bacteriological Analytical Manual ( $8^{\text {th }}$ ed.). https://www.fda.gov/food/laboratory-methodsfood/bam-chapter-5-salmonella

Aymerich, T., Picouet, P.A. \& Monfort, J.M. (2008). Decontamination technologies for meat products. Meat Science, 78, 114-129.

https://doi.org/10.1016/j.meatsci.2007.07.007

Bedane, T.F., Quinn, G., Lyng, J.G. (2021): Microwave and Radio Frequency Processing of Animal-Related Food Products, Innovative Food Processing Technologies 743766.

https://doi.org/10.1016/B978-0-12-815781-7.00014-7

Besser, J.M. (2018). Salmonella epidemiology: A whirlwind of change. Food Microbiology, 71, 55-59. https://doi.org/10.1016/j.fm.2017.08.018

Bookwalter, G.N., Shukla, T.P. \& Kwolek, W.F. (1982). Microwave processing to destroy Salmonella in cornsoy-milk blends and effect on product quality. Journal of Food Science, 47, 1683-1686. https://doi.org/10.1111/j.1365-2621.1982.tb05011.x

Burdick, D., Cox, N.A., Thomson, J.E. \& Bailey, J.S. (1983). Heating by microwave, hot air, and flowing steam to eliminate inoculated Salmonella from poultry feed. Poultry Science, 62, 1780-1785. https://doi.org/10.3382/ps.0621780

Coote, P.J., Holyoak, C.D. \& Cole, M.B. (1991). Thermal inactivation of Listeria monocytogenes during a process simulating temperatures achieved during microwave heating. Journal of Applied Bacteriology, 70, 489-494. https://doi.org/10.1111/j.1365-2672.1991.tb02745.x

D'Aoust, J.Y. (2000). Salmonella. In: B.M. Lund, T.C. BairdParker \& G.W. Gould (Eds.), The Microbiological Safety and Quality of Food, (pp. 1233-1299), Aspen Publishers, Gaithersburg, Maryland.

Das, A., \& Banik, B.K (2021): Chapter 8: Microwave-assisted sterilization in: Microwaves in Chemistry Applications 285-328. ISBN: 9780128228951

Datta, A.K., \& Davidson, P.M. (2001). Microwave and Radio Frequency Processing. Journal of Food Safety, 65, 32-41. https://doi.org/10.1111/j.1750-3841.2000.tb00616.x

Evans, M.R., Parry, S.M. \& Ribeiro, C.D. (1995). Salmonella outbreak from microwave cooked food. Epidemiology \& Infection, 115, 227-230. https://doi.org/10.1017/S0950268800058350

Farber, J.M., D`Aoust. J.Y., Dlotte. M., Sewell, A. \& Daley, E. (1998). Survival of Listeria spp. on raw whole chickens cooked in microwave ovens. Journal of Food Protection, $61,1465-1469$. https://doi.org/10.4315/0362-028X-61.11.1465

Garcia-Linares, M.C., Gonzalez-Fandos, E., Garcia-Arias, M.T. \& Garcia-Fernandez, M.C. (2004). Microbiological and nutritional quality of sous vide or traditionally processed fish: Influence of fat content. Journal of Food Quality, 27, 371-387. https://doi.org/10.1111/j.1745-4557.2004.00676.x

Giese, S. (1992). Advances in microwave food processing. Food Technology, 46, 118-123.

Gomółka-Pawlicka, M., Radkowski, M., Szteyn, J., MigowskaCalik, A. \& Lachowicz, T. (2014). Survival of Salmonella spp. in half carcasses of chicken broilers during microwave cooking. Medycyna Weterynaryjna, 70(11), 693-698. 
Harrison, M.A., \& Carpenter, S.L. (1989). Survival of Listeria monocytogenes on microwave cooked poultry. Food Microbiology, 6(3), 153-157.

https://doi.org/10.1016/S0740-0020(89)80023-1

Heddleson, R.A., \& Doores, S. (1994). Factors affecting microwave heating of foods and microwave induced destruction of foodborne pathogens-a review. Journal of Food Protection, 57(11), 1025-1037. https://doi.org/10.4315/0362-028X-57.11.1025

Hollywood, N.W., Varabioff, Y., \& Mitchell, G.E. (1991). The effect of microwave and conventional cooking on the temperature profiles and microbial flora of minced beef. International Journal of Food Microbiology, 14(1), 67-75. https://doi.org/10.1016/0168-1605(91)90038-Q

Horikoshi, S., Schiffmann, R.F., Fukushima, J. \& Serpone, N. (2018). Microwave as a Heat Source. In: Microwave Chemical and Materials Processing (pp. 1-17). Springer, Singapore. ISBN: 978-981-10-6466-1; DOI: 10.1007/978981-10-6466-1

Huang, Y.W., Leung, C.K., Harrison, M.A., \& Gates, K.W. (1993). Fate of Listeria monocytogenes and Aeromonas hydrophila on catfish fillets cooked in a microwave oven. Journal of Food Science, 58(3), 519-521. https://doi.org/10.1111/j.1365-2621.1993.tb04314.x

Humphrey, T.J., Slater, E., McAlpine, K., Rowbury, R.J., \& Gilbert, R. J. (1995). Salmonella enteritidis phage type 4 isolates more tolerant of heat, acid, or hydrogen peroxide also survive longer on surfaces. Applied and Environmental Microbiology, 61(8), 3161-3164.

Jeong, J.Y., Lee, E.S., Choi, J.H., Lee, J.Y., Kim, J.M., Min, S.G., Chae, Y.C. \& Kim, C.J. (2007). Variability in temperature distribution and cooking properties of ground pork patties containing different fat level and with/without salt cooked by microwave energy. Meat Science, 75(3), 415-422.

https://doi.org/10.1016/j.meatsci.2006.08.010

Juneja, V.K., \& Eblen, B.S. (2000). Heat inactivation of Salmonella typhimurium DT104 in beef as affected by fat content. Letters in Applied Microbiology, 30(6), 461-467.

Levre, E., \& Valentini, P. (1998). Inactivation of Salmonella during microwave cooking. International Journal of Hygiene and Environmental Medicine, 201(4-5), 431436.

Komarov, V.V. (2021): A review of radio frequency and microwave sustainability-oriented technologies, Sustainable Materials and Technologies, 28. https://doi.org/10.1016/j.susmat.2020.e00234

Lindsay, R.E., Krissinger, W.A., \& Fields, B.F. (1986). Microwave vs. conventional oven cooking of chicken: relationship of internal temperature to surface contamination by Salmonella typhimurium. Journal of the American Dietetic Association, 86, 373-374.

https://doi.org/10.1016/j.micres.2006.03.010

Mendes-Oliveira, G., Deering, A.J., San Martin-Gonzalez, M.F., Campanella, O.H. (2020): Microwave pasteurization of apple juice: Modeling the inactivation of Escherichia coli O157: $\mathrm{H7}$ and Salmonella Typhimurium at $80-90{ }^{\circ} \mathrm{C}$, Food Microbiology, 87:103382. https://doi.org/10.1016/j.fm.2019.103382

Orsat, V., Raghavan, G.S.V., \& Krishnaswamy, K. (2017). Microwave technology for food processing: An overview of current and future applications. In: The Microwave Processing of Foods (pp. 100-116), Woodhead Publishing. ISBN: 9781855739642

Paterson, J.L., Cranston, P.M., \& Loh, W.H. (1995). Extending the storage life of chilled beef: Microwave processing. Journal of Microwave Power and Electromagnetic Energy, 30(2), 97-101. https://doi.org/10.1080/08327823.1995.11688263

Picouet, P.A., Fernández, A., Serra, X., Sunol, J.J., \& Arnau, J. (2007). Microwave heating of cooked pork patties as a function of fat content. Journal of Food Science, 72(2), E57-E63. https://doi.org/10.1111/j.1750-3841.2007.00269.x

Pucciarelli, A.B., \& Benassi, F.O. (2005). Inactivation of Salmonella enteritidis on raw poultry using microwave heating. Brazilian Archives of Biology and Technology, 48(6), 939-945.

https://doi.org/10.1590/S1516-89132005000800010

Tassinari, A.D.R., \& Landgraf, M. (1997). Effect of microwave heating on survival of Salmonella typhimurium in artificially contaminated ready-to-eat foods. Journal of Food Safety, 17(4), 239-248. https://doi.org/10.1111/j.1745-4565.1997.tb00191.x

Thostenson, E.T., \& Chou, T.W. (1999). Microwave Processing: Fundamentals and Applications. Composites Part A: Applied Science and Manufacturing, 30(9), 1055-1071. https://doi.org/10.1016/S1359-835X(99)00020-2

Tulsner, M. (1994). Fischverarbeitung. Bd.1Rohstoffeigenschaften von Fisch und Grundlagen der Verarbeitungsprozesse (pp. 19-23), Bekr's Verlag, Hamburg. ISBN-13 : 978-3860221969

Ulusoy, Ş., Üçok Alakavuk, D., Mol, S., Coşansu, S. (2019) Effect of microwave cooking on foodborne pathogens in fish. J Food Process Preserv. 2019; e14045. https://doi.org/10.1111/jfpp.14045

Vela, G.R., \& Wu, J.F. (1979). Mechanism of lethal action of $2,450-\mathrm{MHz}$ radiation on microorganisms. Applied and Environmental Microbiology, 37(3), 550-553.

Vlock, S. (2020): Validation of microwave cooking directions, Development of Packaging and Products for Use in Microwave Ovens (Second Edition), 397-413. https://doi.org/10.1016/B978-0-08-102713-4.00014-1

Woo, I.S., Rhee, I.K., \& Park, H.D. (2000). Differential damage in bacterial cells by microwave radiation on the basis of cell wall structure. Applied and Environmental Microbiology, 66(5), 2243-2247. https://doi.org/10.1128/AEM.66.5.2243-2247.2000

Yılmaz, I., Arıcı, M., \& Gümüş, T. (2005). Changes of microbiological quality in meatballs after heat treatment. European Food Research and Technology, 221(3-4), 281-283. https://doi.org/10.1007/s00217-0051157-9 